\title{
DEMOKRASI, PARTAI POLITIK, DAN PEMILIHAN KEPALA DAERAH
}

\author{
Affan Sulaeman \\ e-mail: affansulaemañomail.com
}

\begin{abstract}
ABSTRAK
Demokratisasi adalah sarana untuk mencapai demokrasi, sehingga ide-ide tentang demokratisasi berkaitan denga strategi untuk mencapai demokrasi. Proses pendirian demokrasiadalahsebuah prosesmenginstitusionalisasikan ketidakpastian, menempatkan semua kepentingan pada ketidakpastian. Partai politik adalah kelompok otonom dari warga negara,memiliki kegunaan dalam membuat nominasinominasi dan peserta pemilu, memiliki keinginan memandu pengawasan pada kekuasaan pemerintahan terus merebut jabatan-jabatan publik dalam organisasi pemerintahan. Fungsi utama partai politik adalah mencari dan mempertahankan kekuasaan guna mewujudkan program-program yang disusun berdasarkan ideologi tertentu.

Pemahaman demokrasi yang paling subtansial adalah pemilihan umum. Pemilihan umum merupakan kesempatan bagi para warga negara untuk memilih pejabat-pejabat dalam pemerintahan dan memut uskan apakah yang merekainginkan untuk dikerjakan oleh pemerintah. Kepala Daerah adalah penanggung-jawab utama dalam penyelenggaraan pemerintahan di daerah. Kepala Daerah akan dinilai rakyat karena saat ini ia dipilih melalui pemilukada secara langsung.

Partai politik pengusung sebelum mendaftarkan calonnya ke KPU Daerah harus telah menemukan pasangan calon yang kapabel dan akuntabel disamping tingkatelektabilitasmemadai.Visi,misi,kebijakan, programseyogyanyadibicarakan secara matang oleh calon kepala daerah dan calon wakil kepala daerah beserta partai politik pengusung. Partai politik pengusung, baik yang ada di gedung DPRD maupun di DPW beserta kadernya, wajib mengawal pasangan terpilih kepala daerah dan wakil kepala daerah. Para pemilih yang telah memberikan suaranya pada pasangan terpilih, tiba waktunya berani menilai kinerja pada kepala daerah dan wakil kepala daerah. Kepala daerah dan wakil kepala daerah saat menjalankan roda pemerintahan harus menghindari budaya rivalitas dan cari popularitas sendirisendiri.
\end{abstract}

Kata kunci: demokrasi, partai politik, pemilihan umum, pemerintahan daerah. 


\begin{abstract}
Democratization is a means to achieve democracy, so the ideas of democratization associated with a strategy to achieve democracy. The process of establishing democracy is a process of institutionalizing uncertainty, putting all of the interests in uncertainty. Political party is an autonomous group from citizens, have a role in making nominations and election participants, and have an interest to guide the supervision of government power to seize public positions in government organizations. The main function of political parties is to find and maintain power in order to actualize programs that has been compiled by a particular ideology.

The most substantial understanding of democracy is elections. Elections is considered as an opportunity for citizens to choose officials in the government and decide what aspects they wanted to be done by the government. Head of Local Government is primarily responsible in the implementation of local government. Head of Local Government will be assessed by the citizens because he was chosen through the direct elections. Those particular political parties before registering their candidates to the Regional Elections Commission shouldhave found a partner candidate that is capable and accountable besides adequate electability level, vision, mission, policies, programs, should be discussed thoroughly by potential candidates for Head of Local Government and its vice together with the political parties itself. Moreover, those political parties, either at DPRD building or at DPW with its cadre, must escort the elected to Head of Local Government and its Vice. Voters whohad used their right to choose the selected partner, it is the right time to dare assessing their performance, and also those selected candidates as Head of Local Government and its Vice in running the government should avoid rivalry culture or find their own popularity.
\end{abstract}

Keynotes: democracy, political parties, elections, local government.

\section{DEMOKRASI DAN DEMOKRATISASI}

Definisi dan terminologi demokrasi sangatlah beragam sebagaimana yang dikutif oleh Esposito tentang bentuk dan istitusi demokrasi yang harus ada dalam suatu pemerintahan yang demokratis. ${ }^{21}$ Adapun demokrasi yang berkembang pada abad XX mengikuti tradisi Schumpeterian, dalam studi ini mendefinisikan bahwa sistem politik yang demokratis sejauh para pembuat keputusan kolektif yang paling kuat dalam sistem itu yang dipilih melalui pemilihan umum yang

21 Chusnul Mari'yah, Islam, Muslim, Demokrasi,dalam Politics of Diference, cmariyahindosat, net.id. 2005 hal. 2. 
adil, jujur, dan berkala. Di dalam sistem itu, para calon secara bebas bersaing untuk memperoleh suara dan hampir semua penduduk dewasa berhak memberikan suara. ${ }^{22}$

Gelombang demokrasi ketiga berjalan secara simultan dan sporadis di banyak negara, dimulai dari Portugal dan Yunani pada tahun 1974 sampai ke Spanyol, Amerika Latin, Uni Soviet, dan Eropa Timur, terus menjalar ke belahan Asia. Terdapat pelbagai faktor penyebab yang berkelindan, yaitu faktor-faktor yang bersifat sosial, ekonomi, kultur, dan internasional. Secara spesifik, faktor internasional ini disebut sebagai "efek bola salju" yang telah merangsang negara-negara lainnya untuk mengubah rezimnya yang otoriter menjadi demokratis. ${ }^{23}$ Dalam masa transisi biasanya terdapat proses politik yang kompleks, melibatkan pelbagai kelompok yang bersaing untukmemperolehkekuasaan. Huntington menyebut ada tiga macam interaksi yang menentukan dalam proses transisi, yaitu (1) interaksi antara pemerintah dan kelompok oposisi, (2) interaksi antara kelompok pembaharu dan konservatif, serta (3) interaksi antara kelompok moderat dan ekstrem dalam kelompok oposisi. ${ }^{24}$ Pada tataran empiris biasanya pada masa transisi peran kelompok pembaharu dan kelompok moderat dalam oposisi menjadi penting untuk menghasilkan proses transisi yang damai.

Berakhirnya kekuasaan rezim lama bukan berarti rezim baru diisi oleh aktor yang sama sekali baru. Terdapat dua kemungkinan, pertama, rezim baru terbentuk sebagai hasil negosiasi para aktor lama dengan aktor baru. Kedua, rezim baruyang terbentuk sama sekali terputus hubungannya dengan rezimlama. Kompetisi antarelit (aktor lama dan aktor baru) dalam rezim baru, biasanya akan sangat menentukan proses transisi berikutnya. Manakala kemungkinan pertama yang munculmakaakandapatmeminimalisir kemungkinan kekerasan dan pertumpahan darah sehingga transisi dapat berjalan mulus. Namum apabila kemungkinan kedua yang terbentuk, maka akan muncul konflik karena aktorlamaselaluberupayamenggoyang rezimyang baruterbentuk. ${ }^{25}$ Sementara pakar politik lain, David Potter, menggunakan transition approach untuk menjelaskan proses politik dan peran elit dalam mendorong perubahan

22 Samuel P. Huntington, Gelombang Demokrasi Ketiga, Jakarta, Grafiti Press, 1995.

23 Samuel P. Huntington, The Third Wave Democratization in the Late Twentieth Century, University of Oklahoma Press, 1991.

24 Ibid, hal. 154.

25 Hal ini mengacu pada pengalaman transisi demokrasi di Spanyol. 
dari pemerintahan otoriter kepada demokrasai liberal. ${ }^{26}$

Demokratisasi erat kaitannya dengan transisi demokrasi. Demokratisasi adalah perubahan politik yang bergerak ke arah demokratis. ${ }^{27}$ Sedangkan, transisi adalah titik awal atau interval masa rezim otoriterian dengan rezim demokratis. Transisi demokrasi mengacu pada sebuah proses untuk mencapai taraf maksimal dari demokratisasi, yaitu konsolidasi demokrasi. Jadi transisi demokrasi itu adalah bagian dari proses demokratisasi. Dengan demikian dapat dikemukakan, demokratisasi adalah sarana untuk mencapai demokrasi, sehingga ide-ide tentang demokratisasi berkaitan dengan strategi untuk mencapai demokrasi. $^{28}$

Larry Diamond berpandangan bahwa jalur negosiasi antara elit rezim lama dan rezim baru akan mengurangi potensi pergolakan dan kekerasan dalam proses transisi, sehingga membuka kemungkinan untuk duduk bersama baik untuk menyusun aturan mainbarumaupununtukmenyelesaikan masalah-masalah lain dalam masa transisi. ${ }^{29}$ Problematika lainnya itu disebut sebagaitigakrisispemerintahan, yaitu (1) tiadanya akuntabilitas dan rule of law, seperti adanya pelanggaran hakazasimanusia(HAM), personalisasi kekuasaan, kekerasan, dan korupsi; (2) ketidakmampuan mengelola konflik etnis dan wilayah; serta (3) krisis ekonomi dan stagnasi ekonomi. ${ }^{30}$

Manakala ketiga persoalan tersebut tidak mampu diselesaikan oleh negara yang baru masuk dalam transisi, bukan tidak mungkin akan terjadi "gelombang balik". Sebaliknya, manakala mampu mengatasinya, maka negara-negara itu memiliki potensi menuju konsolidasi demokrasi. Dalam masa konsolidasi inilah terjadi proses sosialisasi dan internalisasi mengenai sistem yang dipilih (lembaga-lembaga politik demokratis) dan aturan main baru yang sudah disepakati bersama, sehingga muncul komitmen seluruh elemen masyarakat pada aturan main demokrasi. ${ }^{31}$ Dengan demikian maka tiga variabel yang diangggap penting

26 David Poter nampaknya terinpirasi oleh karya Huntington karena berkaitan dengan pengelompokan elit lama dan elit baru dalam transisi demokrasi yang mirip disampaikan oleh Huntington.

27 David Poter, David Goldblati, Margaret Kiloh, Paul Levis, Democratization, Polity Press, 2000, hal.3.

28 Anders Uhlin, Oposisi Berserak, Arus Demokratisasi Gelombang Ketiga di Indonesia, Bandung, Pustaka Mizan, hal. 25

29 Larry Diamond, Developing Democracy Toward Consolidation, Edisi Terjemahan, Yogyakarta, ERE Press, 2003, hal. xviii.

30 Ibid, hal. viii.

31 Ibid, hal. xix. 
semestinya dapat diselesaikan dalam masa transisi demokrasi menuju konsolidasi demokrasi, yaitu (1) pelembagaan politik, (2) aturan main (konstitusi), dan yang terahir adalah (3) budaya demokrasi.

Transisi demokrasi merupakan terminologi yang digunakan oleh Adam Przeworski terutama ketika melakukan kajian untuk melihat proses liberalisasi rezim-rezim otoritarian dan penggantinya menjadi bentuk-bentuk organisasi politik demokratis. Kajian tersebut ditujukan untuk mengetahui prasyarat kondisiterjadinyatranformasi menuju demokrasi di negara-negara yang tertindas oleh pemerintahan otoritarian. ${ }^{32}$ Sedangkkan, hakekat demokrasi adalah tidak ada satupun kepentingan dapat dijamin, yang dimungkinkan adalah kesepakatankesepakatan institusional, yakni kompromi-kompromi mengenai pelbagai institusi yang memungkinkan peluangpeluang yang telah ditetapkan sebelumnya bagi perwujudan pelbagai kepentingan spesifik kelompok. Przeworski menegaskan bahwa bila sebuah transisi damai menuju demokrasi hendak dijalankan, hal utama yang harus ditangani adalah menginstitusionalisasikan ketidak-pastian, tanpa mengancam kepentingan mereka yang masih dapat membalikan proses. Solusi bagi kompromi demokratis terletak pada institusi. ${ }^{33}$ Dengan kata lain bahwa proses pendirian demokrasi adalah sebuah proses menginstitusionalisasikan ketidakpastian, menempatkan semua kepentingan pada ketidakpastian. ${ }^{34}$

\section{APA ITU PARTAI POLITIK?}

Political party is an autonomous group of citizens having the porpose of making nominations and contesting election in hope of gaining control over gavernmental power through the capture of public offices and the organization of the government. ${ }^{35}$ Partai politik adalah kelompok otonom dari warga negara, memiliki kegunaan dalam membuat nominasi-nominasi dan pesertapemilu, memiliki keinginan memandu pengawasan pada kekuasaan pemerintahan terus merebut jabatanjabatan publik dalam organisasi pemerintahan.

Menurut Miriam Budiardjo, partai politik merupakan suatu kelompok terorganisir yang anggota-anggotanya mempunyai orientasi, nilai-nilai, dan

32 Adam Przeworski, Sejumlah Masalah dalam Studi Transisi Menuju Demokrasi, dalam Transisi Menuju Demokrasi, Jakarta, LP3ES, 2003, hal. 75.

33 Ibid, Adam Przeworski, hal . 95.

34 Ibid, Larry Diamond, hal. 95.

35 Robert Huckshorn,Political Parties in America (Monterey,CA:Brooks/Cole,1984,p.10. 
cita-cita yang sama. Tujuan kelompok ini adalah untuk memperoleh kekuasaan politik dan merebut kedudukan politik (biasanya) dengan carakonstitusionaluntukmelaksanakan programnya. ${ }^{36}$ Begitu juga menurut Carl J. Friedrich, partai politik adalah sekelompok manusia yang terorganisir secara stabil dengan tujuan merebut atau mempertahankan pengusaan terhadap pemerintahan bagi pimpinan partainya, dan berdasarkan penguasaan ini, memberikan pada anggota partainya kemanfaatan yang bersifat adil serta material. ${ }^{37}$ Sementara menurut Sigmund Neuman, partai politik adalah organisasi dan aktivisaktivis politik yang berusaha untuk menguasai kekuasaan pemerintahan serta merebut dukungan rakyat melalui persaingan dengan suatu golongan atau golongan-golongan lain yang mempunyai pandangan yang berbeda. ${ }^{38}$ Selanjutnya pakar ilmu politik lainnya, Giovani Sartori, berpendapat bahwa partai politik adalah suatu kelompok politik yang mengikuti pemilihan umum dan melalui pemilihan umum itu, mampu menempatkan caloncalonnya untuk menduduki jabatanjabatan politik. ${ }^{39}$
Secara operasional lebih teknis, sebagaimana digambarkan oleh undang-undang (UU) Politik, yaitu UU No. 2/2008 tentang Partai Politik, menegaskan bahwa pengertian partai politik adalah organisasi yang bersifat nasional dan dibent uk oleh sekelompok warga negara Indonesia secara sukarela atas dasar kesamaan kehendak dan cita-cita untuk memperjuangkan dan membela kepentingan politik anggota, masyarakat, bangsa, dan negara serta memeliharakeutuhanNegaraKesatuan Republik Indonesia berdasarkan Pancasila dan Undang-Undang Dasar Negara Republik Indonesia Tahun 1945. ${ }^{40}$

\section{FUNGSI PARTAI POLITIK}

Fungsi utama dan pertama partai politik adalah mencari dan mempertahankan kekuasaan guna mewujudkan program-program yang disusun berdasarkan ideologi tertentu. Adapun cara yang digunakan oleh suat upartai politikdalam sistempolitik demokrasi dalam rangka mendapatkan dan mempertahankan kekuasaan ialah dengan ikut serta dalam pemilihan

36 Miriam Budiardjo,Dasar-Dasar Ilmu Politik,2008,Jakarta: Gramedia,hal.404.

37 Miriam Budiardjo,Ibid.

38 Sigmund Neuman, Modern Political Parties,dalam Comparative Politics:A Reader,diedit oleh Harry Ecktein dan David E. Apter,1963,London, The Free Press of Glencoe, hal.342.

39 Giovani Sartori,Parties and Party Systems: A Framework for Analysis, 1976,Cambridge University Press,hal.352.

40 Republik Indonesia, UU No.2/2008 tentang Partai Politik,Jakarta,Komisi Pemilihan Umum,2011. 
umum. Partai politik baik dalam sistem politik apapun, apalagi sistem politik demokrasi, iapasti harus melaksanakan sejumlah fungsi, di antaranya: ${ }^{41}$

\section{Sosialisasi Politik}

Yang dimaksud dengan sosialisasi politik adalah proses pembentukan sikap dan orient asi politik para anggota masyarakat, melalui proses sosialisasi politik inilah para anggota masyarakat memperoleh sikap dan orientasi terhadap kehidupan politik yang berlangsung dalam masyarakat. Proses ini berlangsung seumur hidup, baik diperoleh secara sengaja (pendidikan formal, nonformal, informal) maupun secara tidak sengaja (pengalaman sehari-hari dalam keluarga, teman bermain, tetangga, dalam kehidupan bermasyarakat).

\section{Rekrutmen Poltik}

Pengertian rekrutmen politik adalah seleksi dan pemilihan atau pengangkatan seseorang atau sekelompok orang untuk melaksanakan sejumlah peranan dalam sistem politik pada umumnya dan pemerintahan pada khususnya, semakin besar fungsinya manakala partai politik itu mayoritas di parlemen, sehingga berwenang membentuk pemerintahan dalam sistem demokrasi.

\section{Partisipasi Politik}

Partisipasi politik adalah kegiatan warga negara biasa dalam mempengaruhi proses pembuatan dan pelaksanaan kebijakan publik (public policy) dan dalam ikut menentukan pimpinan pemerintahan melalui suatu pemilihan umum yang teratur dan demokratis. Kegiatan dimaksud di ant aranya mengajukan tunt ut an, membayar pajak, melaksanakan keputusan, mengajukan pemimpin, dan mendukung calon pemimpin. Partai politik jugamembukakesempatan,mendorong dan mengajak para anggota dan anggota masyarakat yang lain untuk menggunakan partai politik sebagai saluran kegiatan mempengaruhi proses politik. Dengan demikian, partai politik merupakan wadah partisipasi politik.

\section{Pemadu Kepentingan}

Untuk menampung dan memadukan berbagai kepentingan yang berbeda bahkan bertentangan, maka partai politik dibentuk. Kegiatan menampung, menganalisis, dan memadukan berbagai kepentingan yang

41 Ramlan Surbakti,Memahami Ilmu Politik,1992, Jakarta: Gramedia WidiasaranaIndonesia, hal.116-121.

$18 \mid$ Cosmogov, Vol.1 No.1, April 2015 
berbeda bahkan bertentangan menjadi berbagai alternatif kebijakan publik kemudian diperjuangkan dalam proses pembuatan dan pelaksanaan keput usan politik. Itulah yang dimaksud dengan fungsi pemaduan kepentingan.

\section{Komunikasi Politik}

Komunikasi politik adalah proses penyampaian informasi mengenai politik dari pemerintah kepada warga masyarakat, dan dari warga masyarakat kepada pemerintah. Dalam konteks ini partai politik berfungsi sebagai komunikator politik, tidak terbatas menyampaikan segala keputusan dan penjelasan pemerintah kepada warga masyarakat tetapi juga menyampaikan aspirasi dan kepentingan berbagai kelompok masyarakat kepada pemerintah. Keduanya dilaksanakan oleh partai politik dalam sistem politik demokrasi.

\section{Pengendalian Konflik}

Dalam negara demokrasi, setiap warga negara atau kelompok masyarakat berhak menyampaikan dan memperjuangkan aspirasi dan kepentingannya sehingga konflik merupakan gejala yang sukar dielakan. Sistem politik hanya akan mentolerir konflik yang tidak menghancurkan dirinya, dengan demikian permasalahannya bukan menghilangkan konflik itu, melainkan mengendalikan konflik melalui lembaga demokrasi untuk mendapatkan penyelesaian dalam bentuk keput usan politik. Partai politik sebagai salah satu lembaga demokrasi berfungsi untuk bisa mengendalikan konflik melalui cara dialog dengan pihak-pihak yang berkonflik, menampung dan memadukan berbagai aspirasi dan kepentingan dari pihak-pihak yang berkonflik dan membawa permasalahan kedalam musyawarah badan perwakilan rakyat (DPR) untuk mendapatkan penyelesaian berupa keputusan politik (kompromi di ant ara para wakil rakyat yang berasal dari partai-partai politik).

\section{Kontrol Politik}

Kontrol politik adalah kegiatan untuk menunjukkan kesalahan, kelemahan, dan penyimpangan dalam pengertian bahwa suatu kebijakan (formulasi, implementasi) yang dibuat dan dilaksanakan oleh pemerintah. Pada saat melakukan suatu kontrol politik atau pengawasan harus ada tolok ukur yang jelas sehingga kegiatan itu bersifat relatif obyektif. Adapun tolok ukur suatu kontrol politik berupa nilai-nilai politik yang dianggap ideal dan baik (ideologi) yang dijabarkan kedalam berbagai kebijakan (policy) atau perundang-undangan. Tujuan suatu kontrol politik adalah untuk meluruskan kebijakan terutama pelaksanaan kebijakan yang dianggap menyimpang dan memperbaiki yang keliru, sehingga kebijakan dan pelaksanaannya sejalan dengan tolok 
ukur tersebut. Fungsi kontrol ini adalah merupakan salah satu mekanisme politik dalam sistem politik demokrasi dalam rangka memperbaiki dan memperbaharui dirinya secara terus menerus.

\section{SEBUAH USULAN UNTUK PEMILIHAN KEPALA DAERAH}

Setiap pembicaraan mengenai pemilihan umum, nampaknya tidak bisa dipisahkan dari suatu konsep yang dinamakan "demokrasi". Istilah demokrasi pertama kali diperkenalkan sekitar 2400 tahun yang lalu. Pendapat ini dikemukakan oleh Geovani Sartori. Adalah Herodotus yang dianggap sebagai orang pertama yang mengungkapkan di dalam bukunya "History" dimana kekuasaan (demos) atauorangbanyakharuslahberdasarkan isomania at au persamaan hukum. Dari persamaan tersebut, kemudian berkembang sesuai dengan perkembangan waktu dan tempat atau setting dimana politik berjalan. ${ }^{42}$

Pemahaman demokrasi yang paling subtansial adalah pemilihan umum yang bersifat terbuka dan adil.
Pemilihan umum juga tidak hanya berkaitan dengan kebutuhan pemerintah akan keabsahan kekuasaannya, tetapi juga sebagai sarana rakyat mengartikulasikan aspirasi dan kepentingan dalam kehidupan berbangsa dan bernegara. Mengenai pengertian, pemilihan umum dimaksudkan sebagai sebuah lembaga politik yang mendorong (leads) dan mencerminkan banyak kecenderungan sosial, politik, dan ekonomi. Meski pemilihan umum dan demokrasi bukan konsep yang sinonim, namun adanya pemilihan umum yang bebas dan kompetitiftidak pelak lagi dipandang sebagai salah satu ciri kritis yang menetapkan suatu bangsa sebagai bangsa demokratis. ${ }^{43}$

Pandangan pakar lain, G. Warren dan kawan-kawan, berpendapat bahwa pemilihan umum merupakan kesempatan bagi para warga negara untuk memilih pejabat-pejabat pemerintah dan memutuskan apakah yang mereka inginkan untuk dikerjakan oleh pemerintahan. Dan dalam membuat keputusan itu, para warga negara menentukan apakah yang mereka inginkan untuk dimiliki. ${ }^{44}$ Hal tersebut jugaberkaitandengansistempemilihan

42 Afan Gaffar, "Transisi Menuju Demokrasi:Pelajaran dari Spanyol",Makalah diajukan pada Seminar Pembangunan Politik dan Demokrasi,PAU-SS UGM, Yogyakarta,7-9 September 1989.

43 Laurence Le Duc et.al.,(eds), "Introduction"bagi Comparing Democracies,Election, and Voting in Global Perspective(Thousand Oaks,CA: Sage Publication,1996), hal.4.

44 Harris G. Warren,et.al.,Our Democracy at Work,New York,Printice Hall,Inc,Englewood Cliffs,N.J,1963,hal. 67. 
yang dipakai, atau sistem pemilu. Geovani Sartori pernah berujar bahwa "The Electoral systems is most essensial part of the workings of politicalsystems. Notonlyare electoral systems the most manipulative instrument of politics; but also shape the party system and affect the spectrum of representation". ${ }^{45}$

AGENDA politik paling menyita perhatian bagi rakyat Indonesia adalah penyelenggaraan pemilihan kepala daerah (gubernur/bupati/walikota beserta wakilnya). Tanpa mengurangi arti tentang implementasi penyelenggaran pemerintahan daerah ini, selama praktik telah berjalan, hemat saya, lebih strategis memfokuskan perhatian untuk memilih kepala daerahnya ketimbang wakilnya. Bukan berarti wakil kepaladaerah diangggap tidak penting. Faktanya, wakil kepala daerah secara hirarkhis hanya akan mewakili kepala daerah bilamana sang kepala daerah berhalangan menjalankan tugas. Dalam struktur dan hirarki pemerintahan berdasarkan peraturan dan perundangan diatur serta ditegaskan seperti demikian formulasinya.

Kepala Daerah yang berperan sebagai kepala wilayah administratif adalah penanggung-jawab utama dalam penyelenggaraan pemerintahan di daerah. Di tangan kepala daerahlah suatu daerah akan dinilai berhasil atau gagal, dimana rakyat dan pemerintah pusat (Presiden) berhak mengevaluasinya secara faktual dan menyeluruh. Kepala Daerah akan dinilai rakyat karena saat ini ia dipilih melalui pemilukada. Ia juga akan dinilai oleh pemerintah pusat (Presiden) karena kepala daerah membina wilayah dan mengembangkan wilayah yang merupakan bagian dari penyelenggaraan pemerintahan nasional dalam bingkai Negara Kesatuan Republik Indonesia (NKRI).

Kinerja kepala daerah akan dinilai juga oleh DPRD Provinsi, berkaitan dengan regulasi, anggaran, dan sampai seberapa sukses dalam mengeksekusi kewenangan dan urusan rumah tangga daerah sebagai dampak langsung otonomi daerah. Pada level formulasi pembuatan berbagai kebijakan (Perda dan Anggaran), institusi DPRD Provinsi ikut-serta menyetujuinya. Dalam realitanya, posisi wakil kepala daerah sebenarnya tidak terlihat jelas. Kita baru menyaksikan wakil kepala daerah cenderung berfungsi seputar menjalankan tugas bersifat rutinitas mewakili kepala daerah dan tugas seremonial lainnya, misalnya pembukaan suatu acara yang isinya penuh dengan pidato dan menebar senyum.

45 Deter Nohlen,Elections and Electoral Systems,New Delhi,Mac Millan,India Limited, 1996 hal. 21. 
Belum ada prestasi wakil kepala daerah yang mampu melampui kepala daerahnya. Langkah wakil kepala daerah amat terbatas di samping peraturan perundangan memang demikian adanya mengatur posisi wakil. Namun demikian, kita melihat pemandangan dalam aneka baliho pada event tertentu dan berbagai ucapan via advertensi seolah-olah pemimpin daerah bagaikan dua matahari kembar. Mungkin hal ini diakibatkan saat pencalonan keduanya merasa mampu dan telah berhasil mendulang suara, sehingga ketika pasangan ini terpilih, dua-duanya merasa memiliki saham dalam memenangkan pemilukada. Padahal sudah jelas bahwa kedudukan wakil kepala daerah adalah sebagai orang kedua setelah kepala daerah, kalau tidak mau mengatakan sebagai subordinat kepala daerah belaka secara politis.Maka,didalampenyelenggaraan pemerintahan terdapat dua jenis jabatan bilamana levelnya suatu provinsi. Pertama, pejabat yang dipilih (elected official) yaitu kepala daerah dan wakil wakil kepala daerah. Kedua, pejabat yang diangkat (appoitment official), yaitu sekretaris daerah ke bawah, berdasarkan jenjang herarkhis mengikuti alur kelaziman suatu struktur birokrasi pemerintahan.

Masalahnya sekarang, sering kita saksikan, kenapa seolah di antara kepala daerah dan wakil kepala daerah harus ada kompetisi, bukan saling bekerja-sama dan saling menguatkan pada posisi masing-masing demi soliditas tatakelola pemerintahan. Dengan demikian; visi, misi, dan program pada saat kampanye menjadi manifestasi nyata yang terukur dan dirasakan dampaknya oleh rakyat.

Dalam beberapa kasus, bahkan terdapat kenyataan orang nomer satu dan dua tidak segan untuk bertarung dalam pimilukada berikutnya untuk merebut posisi kepala daerah. Berdasarkan sumber yang bisa dipercaya di salah-satu provinsi malah kepala daerah dan wakil kepala daerah kerap tidak bertegur sapa satu sama lain dan punya agenda sendiri-sendiri. Hal ini tentu saja akan berakibat buruk karena jalannya roda pemerintahan daerah kurang optimal dirasakan rakyat sebagaimana seharusnya. Dampak buruk lainnya, kalangan birokrasi daerah juga merasa kebingungan, bahkan cenderung terfragmentasi menjadi kubu-kubuan. Inilah yang kemudian membuat birokrasi hanya menjalankan tugas rutin akibat dua matahari kembar sedang meredup.

\section{BEBERAPA TEROBOSAN}

Supaya kesalahan politik tidak kembali terulang serta fungsi dan posisi kepala daerah dan wakilnya semakin jelas, saya mengusulkan beberapa langkah krusial.

Pertama, partai politik pengusung sebelum mendaftarkan calonnya ke KPU harus telah menemukan pasangan 
calon yang kapabel dan akuntabel disamping tingkat elektabilitas memadai. Kiranya dapat dipertimbangkan bahwa calon kepala daerah yang akan menentukan siapa calon wakilnya, supaya ketika mereka sama-sama terpilih, wakil kepala daerah merasa direkomendasi oleh kepala daerah. Dengan cara ini sang wakil kepala daerah tidak akan menempatkan diri sebagai rival dan akan loyal bahkan patuh pada kepala daerah, karena yang bersangkutan eksistensinya bisa menjadi wakil kepala daerah karena keinginan dan usulan kepala daerah. Formasi demikian diharapkan pada penyelenggaraan pemerintahan akan menjadi lebih solid dan fungsional. Dengan kata lain, memahami dan bijaksana tau posisi menempatkan diri.

Kedua, visi, misi, kebijakan, program seyogyanya dibicarakan secara matang oleh calon gubernur dan calon wakil gubernur beserta partai politik pengusung, apakah satu partai atau koalisi, dikaitkan dengan ideologi dan platform partai. Terdapat kesan selama ini, hal tersebut digarap secara dadakan dan hanya memakai pola copy-paste dari pengalaman pemilihan kepala daerah di tempat lain oleh tim ahlinya.

Ketiga, partai politik pengusung, baik yang ada di gedung DPRD maupun di DPW beserta kadernya, wajib mengawal pasangan terpilih gubernur dan wakil gubernur, apakah yang bersangkutan mampu menjalan- kan visi, misi, kebijakan, dan program dibingkai oleh ideologi dan platform partai politik secara nyata, sesuai dengan janji kampanyenya. Hal ini merupakanpertanggungjawabanpartai politik pada rakyat pemilih sehingga rakyat percaya pada partai politik tersebut.

Keempat, para pemilih yang telah memberi saham suaranya pada pasangan terpilih, tibawaktunyaberani menilai kinerja pada gubernur dan wakil gubernur. Manakala terdapat problematika yang semestinya merupakan tugas dan kewenangan, sepatutnya mampu ditangani oleh pemerintah provinsi. Rakyat pemilih segera memberi informasi, kemudian segera direspons dan diolah oleh kepala daerah. Dalam konteks situasi seperti ini, kepala daerah bisa menugaskan kepada wakil kepala daerah secara normatif dan fungsional, sehingga ada kejelasan kewenangan. Tak ada lagi bagi-bagi kapling kerja masing-masing dan terkesan tumpang tindih.

Kelima, kepala daerah dan wakil kepala daerah saat menjalankan roda pemerintahan harus menghindari budaya rivalitas dan cari popularitas sendiri-sendiri. Sudah pada tempatnya kedua pasangan tersebut berjuang untuk merealisir janjinya saat kampanye dan berkomitmen membangun daerah dengan segala daya dan upaya memaksimalkan dan menggerakkan sumber daya alam dan sumber daya manusia yang tersedia yang dimiliki di wilayah provinsi yang 
mereka pimpin. Kesempatan dan waktu sepanjang masa jabatan didedikasikan untuk mencari terobosan baru, kreatif, dan bersinergi dengan berbagai stekholders dalam rangka mengukir karya, berdedikasi untuk melindungi, mengembangkan, dan berkhidmat pada kesejahteraan rakyatnya.

\section{DAFTAR PUSTAKA}

Budiardjo,Miriam, 2008. Dasar-Dasar Ilmu Politik. Jakarta: Gramedia.

Diamond, Larry. 2003. Developing Democracytoward Consolidation, Edisi Terjemahan, Yogyakarta: ERE Press.

Gaffar, Afan. "Transisi Menuju Demokrasi: Pelajaran dari Spanyol". Makalah diajukan pada Seminar Pembangunan Politik dan Demokrasi, PAU-SS UGM, Yogyakarta, 7-9 September 1989.

Huckshorn, Robert. Political Parties in America. CA: Monterey.

Huntington, Samuel P., 1995. Gelombang Demokrasi KetigaJakarta: Grafiti Press.

---, 1991. The Third Wave Democratization in the Late Twentieth Century. University of Oklahoma Press.

Le Duc, Laurence,et.al., 1996. "Introduction"bagi Comparing Democracies, Election, and Voting in Global Perspective. Thousand Oaks,CA: Sage Publication.
Mari'yah, Chusnul,2005. "Islam,Mus lim,Demokrasi"dalamPolitics of Diference, cmariyahindosat.net. id.

Neumann, Sigmund, 1963. "Modern Political Parties"dalam Comparative Politics: A Reader,diedit oleh Harry Ecktein dan David E. Apter. London: The Free Press of Glencoe, hal.342.

Nohlen, Deter, 1996. Elections and Electoral Systems. New Delhi: Mac MillanIndia Ltd.

Poter, David,et.al., 2000. Democratization, Polity Press.

Przeworski, Adam, 2003. "Sejumlah Masalah dalam Studi Transisi Menuju Demokrasi" dalam Transisi Menuju Demokrasi. Jakarta: LP3ES.

Republik Indonesia, UU No.2/2008 tentang Partai Politik. Jakarta: Komisi Pemilihan Umum.

Sartori, Giovani, 1976.Parties and Party Systems: A Framework for Analysis, Cambridge University Press,hal.352.

Surbakti, Ramlan, 1992. Memahami Ilmu Politik. Jakarta: Gramedia Widiasarana Indonesia.

Uhlin, Anders. Oposisi Berserak:Arus Demokratisasi Gelombang Ketiga di Indonesia. Bandung: Pustaka Mizan.

Warren, Harris G., et.al., Our Democracy at Work. New York: PrenticHall, Inc. Englewood Cliffs. 